\title{
Waste Management and Sustainability: Indicators under Ecological Economy Perspective
}

\author{
Natália Molina Cetrulo ${ }^{1}$, Tiago Balieiro Cetrulo ${ }^{2}$, Sylmara Lopes Francelino Goncalves-Dias ${ }^{1} \&$ Rodrigo \\ Martins Moreira ${ }^{3}$ \\ ${ }^{1}$ School of Arts, Sciences and Humanities, University of Sao Paulo, Brazil \\ ${ }^{2}$ School of Engineering, University of Sao Paulo, Brazil \\ ${ }^{3}$ Environmental Management, Mato Grosso do Sul State University, Brazil \\ Correspondence: Natália Molina Cetrulo, School of Arts, Sciences and Humanities, University of Sao Paulo, \\ Brazil.
}

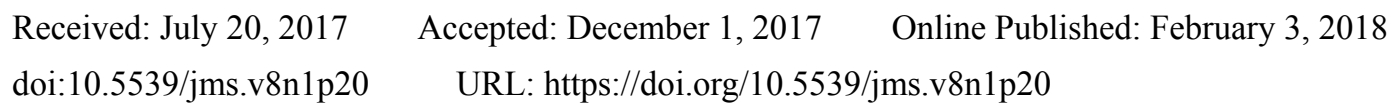

\begin{abstract}
For indicators to assess a society's sustainability it is necessary that the understanding of what type of sustainability one wishes to measure is clear. The hypothesis tested in the present study is that solid waste management indicators, used in city sustainability assessments, do not represent the concept of strong sustainability. To test the hypothesis, the article initially identifies the perspectives of solid waste management from the strong sustainability's point of view, under Ecological Economy perspective. The hypothesis was tested in thirteen sustainability assessment tools, covering approximately 400 cities. Two, out of five perspectives identified, had indicators selected represent them. Only one system presented three perspectives, and eight presented two. To represent the theme's complexity, all perspectives should be considered, so the hypothesis formulated was accepted.
\end{abstract}

Keywords: strong sustainability, ecological economics, sustainability assessment, solid waste, sustainability indicators

\section{Introduction}

Sustainability indicators are tools used to support decision-making, by providing information, and contribute to sustainable development policies planning, implementation and evaluation (Bossel, 1999; Dahl, 1997). The United Nations Conference on Sustainable Development (United Nations Conference on Sustainable Development [UNCED], 1992) highlighted its key role for management processes, since then, several sustainability-based assessment instruments have emerged to tackle society's sustainable development. This paper focuses on indicators to support cities sustainability assessments (Bohringer \& Jochem, 2007; Moreno-Pires \& Fidelis, 2012; Ness, Urbel-Piirsalu, Anderberg, \& Olsson, 2007; Rametsteiner, Pülzl, Alkan-Olsson, \& Frederiksen, 2011; Tanguay, Rajaonson, Lefebvre, \& Lanoie, 2010).

Although sustainability indicators are major tools for a given system evaluation, they present weaknesses in selection processes, therefore, leading to a system with problems (Gibson, Hassan, Holtz, Tansey, \& Whitelaw, 2005). Thus, Meadows (1998) states that for a set of indicators to be valid alternatives to describe society's sustainability, the first step is to identify how that society understands sustainability and then to tackle how indicators can represent that understanding.

City sustainability assessment methodologies have incorporated solid waste management indicators, as presented by Atkisson (1996), Huang, Wong, \& Chen (1998), Diamantini \& Zanon (2000), Portney (2001), Dijl \& Mingshun (2005), Nader, Salloum, \& Karam (2008), Li et al. (2009), Scipioni, Mazzi, Mason, \& Manzardo (2009), Tanguay et al. (2010), Shen, Ochoa, Shah, \& Zhang (2010), Moussiopoulos, Achillas, Vlachokostas, Spyridi, \& Nikolaou (2010), Rosales (2011), and Lucena, Cavalcante, \& Cândido (2011). Nevertheless, heterogeneity in indicators used to represent this sustainability aspect, leads to questions about the real scope and purpose of these indicators. Specifically regard understanding how these indicators represent sustainability.

Considering this context, this work's hypothesis is: solid waste management indicators, used in city sustainability assessment, are not being selected to represent a strong sustainability from ecological economy's 
perspective.

In order to do so, the paper was divided in four sections, where the first section presents sustainability through ecological economy perspective, the second section presents solid waste management through ecological economy perspective, the third section tests the hypothesis in thirteen cities' sustainability assessments by using perspectives previously identified, and the last section discusses the final considerations.

\section{Sustainability under Ecological Economy Perspective}

Ecological Economy is a scientific school linked to sustainability, one of its possible classifications is "Science and Sustainability Management" (Constanza, 1991) and one of its purposes is to say to what extent the use of nature can be done sustainably (Cavalcanti, 2010). The point of departure of this science is linked to the term strong sustainability, under the focus of the irreplaceability of natural capital (Constanza \& Daily, 1992; Daily, 1991).

In this understanding, sustainability translates into physical stocks of natural capital maintenance and not their monetary values, that is, natural capital and constructed capital cannot be exchanged by each other (Pelec \& Ballet, 2015).

It is also intrinsic to this understanding the intergenerational aspect regarding future generations' justice and equality of opportunity in natural resources access (Klassen \& Opschoor, 1991; Kates, Parris, \& Leiserowitz, 2005).

In general, Ecological Economy concepts regarding sustainability are associated with the material and energetic aspects of economic activities (Constanza, 1991; Daly \& Farley, 2004) using the second law of thermodynamics (Law of entropy), in addition to concepts of energy flow, mass conservation and supportability. Unlike reductionism of "circular diagram of economics" underpinned by conventional economics, the ecological economy sees the economic system as an open system, in constant interaction with the environment. This means that capital flows are linked to energy flows that have environmental impacts (Odum, 1973). Thus, entropy inputs and energy are used by economic systems to produce goods, services, and waste, degraded matter and high entropy dissipated energy (Georgescu-Roegen, 1971).

Therefore, Ecological Economy sustainable development respects the Earth's finite capacity to provide energy and material resources as input to economic systems and to absorb residues (Odum, 1973; Daly, 1992).

\section{Identifying Ecological Economy Perspectives Regarding Solid Waste Management}

Ecological economy perspectives were identified through systematic literature review structured in three steps. The first step consisted of searching relevant articles in Science Direct, Web of Science and Scopus scientific databases. In total, 205 results were found in the database Science Direct, 199 on Scopus and 28 on Web of Science. From 432 results, 35 were repeated reaching a total of 397 relevant articles. In the second stage, exclusion criteria were used to select most relevant publications. Thirty-one results from Science Direct, 23 from Scopus and 8 from the Web of Science, with 325 remaining papers. In the last step these articles were analyzed in relation to the following question: What are the perspectives presented by ecological economy regarding solid waste management? Among 325 papers analyzed, 66 presented perspectives on solid waste management, presented below.

A first ecological economy perspective regarding solid waste management was identified in 25 articles and concerns society, economy, and environment input-output relationship, in which energy and materials are withdrawn from environment (low entropy) and return in different forms of waste (high entropy). This view is based on the Law of Entropy (Second Law of Thermodynamics) and relates to flow of matter and energy concepts, ecological economy founding bases discussed by Georgescu-Roegen (1971), Odum (1973), Daly e Farley (2004).

The second ecological economy perspective, identified in 18 articles, relates the solid waste issue to mass conservation throughout society's production and consumption processes. Resources are removed from the environment to be used by economic systems and return to the environment as waste, but mass amount does not change in time, changing only its shape. In this case, materials can be disposed in the environment as tailings from production processes or can be reinserted into economic systems through recycling.

Ecosystems physical limit in providing resources and assimilating residues from economic systems, the supportability principle of Ecological Economy, motivated the base perspective, adding a total of 26 works. These articles presented a point of view that demonstrates concern with the relationship between final disposition of residues and ecosystem's assimilation capacity. Discussions regarding this relationship consider economic 
system aspects, level of consumption, and scale of intervention in the environment and sustainability of society.

Another perspective was that waste can interact with other ecological components and affect ecological supplies for economic sector. Nine papers addressed solid waste pollution issues from irreversibility point of view. These works understand that solid waste pollutants have potential to transform usable resources into non-usable resources, therefore, related to the Entropy of Ecological Economics.

Finally, eight papers tackled the waste issue from social inequalities perspective, between cities' core and peripheral communities. From this point of view regards to issues, for instance, disposal of hazardous waste at poor countries, disposal of hazardous waste in cities' poor areas and other forms of disrespect to those less favored by the social system.

Ecological economy perspectives, the work in which they were identified, and the principles of sustainability to which they relate are presented in Table 1.

Table 1. Ecological economy perspectives on solid waste management, sources and related principles of sustainability

\begin{tabular}{|c|c|c|}
\hline Sources & $\begin{array}{l}\text { Perspectives regarding } \\
\text { solid waste management }\end{array}$ & $\begin{array}{l}\text { Principle } \\
\text { Sustainability }\end{array}$ \\
\hline $\begin{array}{l}\text { Ingebrigtsen \& Jakobsen (2012), Nadeau (2015), Weaver (2013), Røpke (2004), } \\
\text { Martinez-Alier (1997), Rammelt \& Boes (2013), Pelletier (2010), Røpke } \\
\text { (2009), Klaassen \& Opschoor (1991), Darwin, Tsigas, Lewandrowski, \& } \\
\text { Raneses (1996), Binswanger (1993), Nihoul (1998), Sousa \& Domingos (2006), } \\
\text { Stahel (2005), Farley \& Costanza (2010), Pearce (1987), Ockwell (2008), Chee } \\
\text { (2004), Buenstorf (2000), Christensen (1989), O’Connor (1991), Burkett \& } \\
\text { Foster (2006), Lawn (2001), Özkaynak, Adaman, \& Devine (2012) e Hodas } \\
\text { (2013). }\end{array}$ & $\begin{array}{l}\text { Waste as a component } \\
\text { that increases the } \\
\text { system's entropy. }\end{array}$ & $\begin{array}{l}\text { Law of entropy / flow } \\
\text { of matter and energy. }\end{array}$ \\
\hline $\begin{array}{l}\text { Victor (2015), Shi (2002), Røpke (2004), Martinez-Alier (1997), Stem (1997), } \\
\text { Kiaassen \& Opschoor (1991), Ferraro \& Reid (2013), Common (2007), } \\
\text { McMahon (1997), Noël, O’Connor, \& Sang (2000), Schandl \& Schulz (2002), } \\
\text { Røpke (2016), Crane \& Swilling (2008), Korhonen \& Niutanen (2003), Macrae, } \\
\text { Henning, \& Hill (1993), Lintott (1998), Lawn (2001) e Farley \& Costanza } \\
\text { (2010). }\end{array}$ & $\begin{array}{l}\text { Conservation of matter } \\
\text { between resource and } \\
\text { waste relations, and } \\
\text { vice-versa. }\end{array}$ & Mass conservation. \\
\hline $\begin{array}{l}\text { Pelletier (2010), Pelletier, Maas, Goralczyk, \& Wolf (2014), Giampietro \& } \\
\text { Saltelli (2014), Friend \& Rapport (1991), Weaver (2013), Klitgaard \& Krall } \\
\text { (2012), Forstater (2004), Andrade \& Garcia (2015), Rammelt \& Boes (2013), } \\
\text { Pelletier (2010), Farley et al. (2007), Common \& Perrings (1992), Ferng (2007), } \\
\text { Erb et al. (2009), Curtis (2003), Farley \& Costanza (2010), Pearce (1987), } \\
\text { Common (2007), Ulhøi (1995), Duxbury and Dickinson (2007), Bojković, } \\
\text { IAnić, \& Pejčić-Tarle (2010), Farley \& Costanza (2010), Guzmán, Molina, \& } \\
\text { Alonso (2011), Meppem \& Gill (1998), Schandl \& Schulz (2002), Jenkins } \\
\text { (1996), Nobre, Musango, Wit, \& Ferreira (2009), Summers et al. (2012), Røpke } \\
\text { (2016) e Lawn (2001). }\end{array}$ & $\begin{array}{l}\text { Ecosystem's finite } \\
\text { capacity to assimilate } \\
\text { waste. }\end{array}$ & Supportability. \\
\hline $\begin{array}{l}\text { Røpke (2004), Common \& Perrings (1992), Martinez-Alier (2001), Huber } \\
\text { (2009), Friend \& Rapport (1991), Lawn (2001), Faber et al. (2005), Ulhøi } \\
\text { (1995) e Warlenius, Pierce, \& Ramasar (2015). }\end{array}$ & $\begin{array}{l}\text { Pollution by rolid waste } \\
\text { increases } \\
\text { entropy. }\end{array}$ & $\begin{array}{l}\text { Law of entropy / flow } \\
\text { of matter and energy. }\end{array}$ \\
\hline $\begin{array}{l}\text { O'Hara (2009), Warlenius, Pierce, \& Ramasar (2015), Martinez-Alier (2001), } \\
\text { Roberts (2011), Berrens \& Polasky (1995), Schneider, Kallis, \& Martinez-Alier } \\
\text { (2010), Martinez-Alier (1997) e Rammelt \& Boes (2013). }\end{array}$ & $\begin{array}{l}\text { Social asymmetries and } \\
\text { waste disposal. }\end{array}$ & Environmental justice. \\
\hline
\end{tabular}

\section{Indicators of Solid Waste Management from the Perspective of the Ecological Economy}

In this section, sustainability perspectives raised in the previous section were used as subsidy to perform an analysis regarding solid waste management indicators, used in thirteen sustainability assessment exercises executed in almost 400 cities. Among these tools, nine were applied in only one city, Trento, Padua, Jining, Taipei, Seattle, Iserlohn, Thessaloniki, Mexico City and João Pessoa and four assess sustainability of more than one city, see Table 2. 
Table 2. Cities were indicators for sustainability assessment of ecological economy perspective regarding solid waste management were carried out

\begin{tabular}{|c|c|c|c|}
\hline Cities & Source & Indicators used & Perspectives \\
\hline Trento (Italy) & $\begin{array}{l}\text { Diamantini \& Zanon } \\
(2000)\end{array}$ & Final disposal of waste & $\begin{array}{l}\text { Waste as a component that increases } \\
\text { system's entropy }\end{array}$ \\
\hline 44 cities in Lebanon & $\begin{array}{l}\text { Nader, Salloum, \& } \\
\text { Karam (2008) }\end{array}$ & $\begin{array}{l}\text { Household waste disposal } \\
\text { Solid waste generation at city } \\
\text { Composition of municipal waste } \\
\text { Healthcare waste generation } \\
\text { Problems in solid waste disposal } \\
\text { Number of households without collection }\end{array}$ & $\begin{array}{l}\text { Conservation of matter between resource } \\
\text { and waste relations and vice-versa. } \\
\text { Pollution due to waste increasing } \\
\text { system's entropy. } \\
\text { Waste as a component that increases } \\
\text { system's entropy }\end{array}$ \\
\hline Pádua (Italy) & Scipioni at al. (2009) & $\begin{array}{l}\text { Waste generation } \\
\text { Recycling }\end{array}$ & $\begin{array}{l}\text { Conservation of matter between resource } \\
\text { and waste relations and vice-versa. } \\
\text { Waste as a component that increases } \\
\text { system's entropy }\end{array}$ \\
\hline $\begin{array}{l}\text { More than } 300 \text { cities in } \\
\text { developed } \quad \text { western } \\
\text { countries }\end{array}$ & Tanguay et al. $(2010)^{*}$ & $\begin{array}{l}\text { Quantity of waste generated } \\
\text { Amount of recycled waste }\end{array}$ & $\begin{array}{l}\text { Waste as a component that increases } \\
\text { system's entropy } \\
\text { Conservation of matter between resource } \\
\text { and waste relations and vice-versa. }\end{array}$ \\
\hline Jining (China) & Li et al. (2009) & $\begin{array}{l}\text { Urban waste proportion treated according } \\
\text { to national standards } \\
\text { Industrial waste proportion treated } \\
\text { according to national standards }\end{array}$ & $\begin{array}{l}\text { Conservation of matter between resource } \\
\text { and waste relations and vice-versa. } \\
\text { Pollution due to waste increasing } \\
\text { system's entropy }\end{array}$ \\
\hline Taipei (China) & Huang et al. (1998) & $\begin{array}{l}\text { Waste generation per capita } \\
\text { Percentage of recycled waste }\end{array}$ & $\begin{array}{l}\text { Waste as a component that increases } \\
\text { system's entropy } \\
\text { Conservation of matter between resource } \\
\text { and waste relations and vice-versa. }\end{array}$ \\
\hline Seattle (US) & Atkisson (1996) & $\begin{array}{l}\text { Generation per capita waste } \\
\text { Percentage of recycled waste }\end{array}$ & $\begin{array}{l}\text { Waste as a component that increases } \\
\text { system's entropy } \\
\text { Conservation of matter between resource } \\
\text { and waste relations and vice-versa. }\end{array}$ \\
\hline 24 US cities & Portney (2001) & $\begin{array}{l}\text { Recycling of household waste } \\
\text { Recycling of industrial waste } \\
\text { Recycling of hazardous waste }\end{array}$ & $\begin{array}{l}\text { Conservation of matter between resource } \\
\text { and waste relations and vice-versa. }\end{array}$ \\
\hline 4 cities in China & $\begin{array}{l}\text { Dijl \& Mingshun } \\
(2005)\end{array}$ & Percentage of recycled waste & $\begin{array}{l}\text { Conservation of matter between resource } \\
\text { and waste relations and vice-versa. }\end{array}$ \\
\hline 9 cities in China & Shen et al. (2011) & $\begin{array}{l}\text { Percentage of population with regular } \\
\text { collection } \\
\text { Percentage of final destination } \\
\text { Generation per capita waste } \\
\text { Generation of hazardous waste } \\
\text { Treatment and final disposal } \\
\text { Management of radioactive waste }\end{array}$ & $\begin{array}{l}\text { Waste as a component that increases } \\
\text { system's entropy } \\
\text { Pollution due to waste increases the } \\
\text { entropy of the system. }\end{array}$ \\
\hline Thessaloniki (Greece) & $\begin{array}{l}\text { Moussiopoulos et al. } \\
(2010)\end{array}$ & $\begin{array}{l}\text { Generation per capita waste } \\
\text { Waste characterization } \\
\text { Recycling } \\
\text { Production and treatment } \\
\end{array}$ & $\begin{array}{l}\text { Waste as a component that increases } \\
\text { system's entropy } \\
\text { Conservation of matter between resource } \\
\text { and waste relations and vice-versa. }\end{array}$ \\
\hline Mexico CIty (Mexico) & Rosales (2011) & $\begin{array}{l}\text { Generation per capita waste } \\
\text { Generation of construction waste } \\
\text { Screening }\end{array}$ & $\begin{array}{l}\text { Waste as a component that increases } \\
\text { system's entropy } \\
\text { Conservation of matter between resource } \\
\text { and waste relations and vice-versa. }\end{array}$ \\
\hline João Pessoa (Brazil) & $\begin{array}{l}\text { Lucena \& Cavalcante } \\
\text { e Cândido (2011) }\end{array}$ & $\begin{array}{l}\text { Expenditure on municipal solid waste } \\
\text { Recycling rate in relation to the amount of } \\
\text { household waste and public waste } \\
\text { Recovered mass from selective collection }\end{array}$ & $\begin{array}{l}\text { Conservation of matter between resource } \\
\text { and waste relations and vice-versa. }\end{array}$ \\
\hline
\end{tabular}

Note. $*$ In this paper are presented only indicators that were used in six or more cities.

Analysis results are presented discussing the whole set of indicators. As can be seen in the fourth column of

Table 2, from thirteen city sustainability assessment indicators, only one presents three Ecological Economics 
perspectives for solid waste management, eight present two perspectives, and four present only one perspective. This means that indicators that were designed were not based or constructed to represent strong sustainability concepts, analyzing through Ecological Economy perspective.

These results regarding 400 cities studied are of major importance. The fact that from five Ecological Economics perspectives identified on solid waste management, only three were contemplated ("Waste as a component that increases the entropy of the system", "Conservation of matter between resource and waste relations" and "Pollution due to waste increasing system's entropy") and for ("Ecosystem's finite capacity to assimilate waste" and "social asymmetries and waste disposal"), no system has devised indicators to represent them. These findings reinforce results importance.

Most of analyzed works present indicators regarding amount of waste that society generates and recyclable percentage that returns to economic systems. These indicators, respectively, can be used to represent system's entropy increase level, by generation of non-usable resources and mass conservation by usable inputs from "theoretically" unusable resources.

Although the principle of mass conservation is represented by recycling indicators, it is important to consider that recycling is not always environmentally and economically feasible, since recycled materials gradually lose their functional characteristics (Kronenberg, 2007) and recycling process generates dissipation of high entropy energy that cannot be reused (Klaassen \& Opschoor, 1991). And these aspects, based on Ecological Economy perspectives of Law of entropy and matter and energy flow, should also be represented by sustainability indicators.

Other indicators studied, include, to a lesser extent, questions of final disposal and treatment of waste, especially those with large pollution risk. From Ecological Economy perspective, these indicators can be used to prevent loss of public health due to wastes' pollution potential, when disposed in natural areas present risk to natural resources.

However, final disposal of waste in landfills disrespects intergenerational equity, under premise of Ecological Economy. The area used for waste disposal restricts its use, which affects negatively equal opportunity of future generations to access that specific area's resources. In addition, there is a risk of unplanned pollution impacts occurred from depleted landfill sites.

One of Ecological Economy's main foundations is ecosystem's physical capacity to provide resources to, and assimilate residues of, economic systems. However, none of sustainability assessment systems analyzed contemplated the supportability principle. The generation of municipal waste allows to foretaste the degree of natural resources exploitation (Pelletier, 2010), but does not provide any representation for assimilation of waste capacity.

Although ecosystem's ability to support is an essential Ecological Economics perspective in solid waste management, establishing ecosystem support capacity is not an easy task, especially when different ecosystems are considered to have different rates of waste assimilation.

In this sense, in the absence of a specified value for waste amounts of that could be generated without exceeding ecosystems potential to assimilate them, an alternative way to represent this principle, using waste assimilation indicators, would be to consider the area used by the city. Despite weaknesses, for instance, the fact that all ecosystems are considered to have the same rate of waste assimilation and if they do not continue to work with a scientific physical limit, the use of this indicator alongside with an evaluation standard would allow a prediction regarding the intervention intensity in the environment. Thus, it is key to use the "area" variable, which would result in waste generation / area of the city, into the waste generation indicator, which is already widely disseminated and used by sustainability assessment tools.

It was found that social aspects of solid waste management were also not considered in discussions of analyzed works as a system's limitation. In this sense, it is questioned whether the absence of these aspects in solid waste problem is due to lack of information by local city responsible, since most of assessment tools use available information, not always reliable or existing, or if a trans disciplinary approach, major key for sustainability initiatives, is being considered or whether there is a prevalence of environmental dimension.

\section{Final Considerations}

Considering sustainability assessment tools and their indicators main objective is to support for decision-making tackling a more sustainable society (Ness et al., 2007), it is essential that the understanding regarding sustainability is well defined so systems are able to accomplish a purposeful pursuit. 
A starting point to discuss sustainability assessment tools is the use of indicators to express reality complexity. And this limitation causes even greater problems when it is not clear what one wants to measure.

In this paper, it was proposed that solid waste management indicators used in sustainability assessments should be analyzed in relation to their capacity to actually represent sustainability aspects.

The main results of this paper are: an analysis structure for solid waste indicators used in sustainability assessment tools and an application in 13 works that presented sustainability assessment tools in approximately 400 cities.

The structure is composed of five perspectives of strong sustainability according to ecological economy: "Waste as a component that increases the entropy of the system", Conservation of matter between resource and waste relations and vice-versa, "Finite capacity of the ecosystem to assimilate waste", "Pollution due to waste increasing system's entropy" and "Social asymmetries and waste disposal". This structure can be applied both to indicators development and to perform assessments at different spatial scales.

Cases studied were deployed at cities scale and results showed that indicators used to evaluate the solid waste management aspect were not selected and used based on the ecological economy's strong sustainability. Therefore, the hypothesis formulated was accepted.

Two explanations are possible regarding to this and are hypotheses to be studied in future works: 1) Current tools used to assess cities sustainability do not accomplish ecological economy's strong sustainability purpose; 2) Indicators selection is not carried out in a judicious way to represent the reality of the place studied.

\section{Acknowledgments}

The authors acknowledge the financial support from CAPES - Coordination for the Improvement of Higher Education Personnel.

\section{References}

Andrade, D. C., \& Garcia, J. R. (2015). Estimating the Genuine Progress Indicator (GPI) for Brazil from 1970 to 2010. Ecological Economics, 118, 49-56. https://doi.org/10.1016/j.ecolecon.2015.07.018

Atkisson, A. (1996). Developing indicators os sustainable community: lessons from Sustainable Seattle. Environmental Impact Assessment Review, 16, 337-350. https://doi.org/10.1016/S0195-9255(96)00025-X

Berrens, R. P., \& Polasky, S. (1995). The Paretian Liberal Paradox and ecological economics. Ecological Economics, 14(1), 45-56. https://doi.org/10.1016/0921-8009(95)00010-7

Binswanger, M. (1993). From microscopic to macroscopic theories: entropic aspects of ecological and economic processes. Ecological Economics, 8, 209-233. https://doi.org/10.1016/0921-8009(93)90059-F

Böhringer, C., \& Jochem, P. E. P. (2007). Measuring the immeasurable-A survey of sustainability indices. Ecological Economics, 63, 1-8. https://doi.org/10.1016/j.ecolecon.2007.03.008

Bojković, N., Ianić, A., \& Pejčić-Tarle, S. (2010). One solution for cross-country transport-sustainability evaluation using a modified ELECTRE method. Ecological Economics, 69(5), 1176-1186. https://doi.org/10.1016/j.ecolecon.2010.01.006

Bossel, H. (1999). Indicators for sustainable development: Theory, Method, application: A report of the Balaton Group. Winnipeg, International Institute for Sustainable Development, Canada.

Buenstorf, G. (2000). Self-organization and sustainability: energetics of evolution and implications for ecological economics. Ecological Economics, 33, 119-134. https://doi.org/10.1016/S0921-8009(99)00133-0

Burkett, P., \& Foster, J. B. (2006). Metabolism, energy, and entropy in Marx's critique of political economy: Beyond the Podolinsky myth. Theory and Society, 35, 109-156.

Cavalcanti, C. (2010). Concepções da economia ecológica: suas relações com a economia dominante e a $\begin{array}{llll}\text { economia ambiental. } & \text { Estudos }\end{array}$ http://dx.doi.org/10.1590/S0103-40142010000100007

Chee, Y. E. (2004). An ecological perspective on the valuation of ecosystem services. Biological Conservation, 120, 549-565. https://doi.org/10.1016/j.biocon.2004.03.028

Christensen, P. P. (1989). Historical roots for ecological economics-biophysical versus allocative approaches. Ecological Economics, 1(1), 17-36. https://doi.org/10.1016/0921-8009(89)90022-0

Common, M. (2007). Measuring national economic performance without using prices. Ecological Economics, 
64(1), 92-102. https://doi.org/10.1016/j.ecolecon.2007.07.017

Common, M., \& Perrings, C. (1992). Towards an ecological economics of sustainability. Ecological Economics, 6(1), 7-34. https://doi.org/10.1016/0921-8009(92)90036-R

Costanza, R. (1991). Ecological economics: the science and management of sustainability. New York: Columbia University Press

Costanza, R., \& Daly, H. E. (1992). Natural Capital and Sustainable Development. Conservation Biology, 6(1), $37-46$.

Crane, W., \& Swilling, M. (2008). Environment, Sustainable Resource Use and the Cape Town Functional Region-An Overview. Urban Forum, 19, 263-287.

Curtis, F. (2003). Eco-localism and sustainability. Ecological Economics, 46(1), 83-102. https://doi.org/10.1016/S0921-8009(03)00102-2

Dahl, A. L. (1997). The big picture: comprehensive approaches. In B. Moldan \& S. Bilharz (Ed), Sustainability Indicators: report of the project on indicators of sustainable development. Chichester: John Wiley \& Sons Ltda.

Daly, H. (1991). Elements of environmental macroeconomics. In R. Costanza (Org.), Ecological economics: the science and management of sustainability. New York: Columbia University Press.

Daly, H. (1992). Allocation, distribution, and scale: towards an economics that is efficient, just, and sustainable. Ecological Economics, 6, 185-193. https://doi.org/10.1016/0921-8009(92)90024-M

Daly, H., \& Farley, J. (2004). Ecological Economics: Principles and Applications. Island Press, Washington.

Darwin, R., Tsigas, M., Lewandrowski, J., \& Raneses, A. (1996). Land use and cover in ecological economics. Ecological Economics, 17, 157-181. https://doi.org/10.1016/S0921-8009(96)80004-8

Diamantini, C., \& Zanon, B. (2000). Planning the urban sustainable development the case of the plan for the province of Trento, Italy. Environmental Impact Assessment Review, 20, 299-310. https://doi.org/10.1016/S0195-9255(00)00042-1

Dijk, M. P. V., \& Mingshun, Z. (2005) Sustainability indices as a tool for urban managers, evidence from four medium-sized Chinese cities. Environmental Impact Assessment Review, 25, 667-688. https://doi.org/10.1016/j.eiar.2004.10.001

Duxbury, J., \& Dickinson, S. (2007). Principles for sustainable governance of the coastal zone: In the context of coastal disasters. Ecological Economics, 63(2-3), 319-330. https://doi.org/10.1016/j.ecolecon.2007.01.016

Erb, K. Z., Krausmann, F., Gaube, V., Gingrich, S., Bondeau, A., Fischer-Kowalski, M., \& Haberl, H. (2009). Analyzing the global human appropriation of net primary production - processes, trajectories, implications. An introduction. Ecological Economics, 69(2), 250-259. https://doi.org/10.1016/j.ecolecon.2009.07.001

Faber, M., Frank, K., Klauer, B., Manstetten, R., Schiller, J., \& Wissel, C. (2005). On the foundation of a general theory of stocks. Ecological Economics, 55(2) 155-172. https://doi.org/10.1016/j.ecolecon.2005.06.006

Farley, J., \& Costanza, R. (2010). Payments for ecosystem services: From local to global. Ecological Economics, 69, 2060-2068. https://doi.org/10.1016/j.ecolecon.2010.06.010

Farley, J., Baker, D., Batker, D., Koliba, C., Matteson, R., Mills, R., \& Pittman, J. (2007). Opening the policy window for ecological economics: Katrina as a focusing event. Ecological Economics, 63(2-3), 344-354. https://doi.org/10.1016/j.ecolecon.2006.07.029

Ferng, J. J. (2007). Biophysical assessments in evaluating industrial development: An experience from Taiwan $\begin{array}{lllll}\text { freshwater aquaculture. } & \text { Ecological } & \text { Economics, } & 63(2-3), & \text { 427-434. }\end{array}$ https://doi.org/10.1016/j.ecolecon.2006.11.009

Ferraro, E., \& Reid, L. (2013). On sustainability and materiality. Homo faber, a new approach. Ecological Economics, 96, 125-131. https://doi.org/10.1016/j.ecolecon.2013.10.003

Forstater, M. (2004). Visions and scenarios: Heilbroner's worldly philosophy, Lowe's political economics, and the methodology of ecological economics. Ecological Economics, 51(1-2), 17-30. https://doi.org/10.1016/j.ecolecon.2004.07.015

Friend, A. M., \& Rapport, D. J. (1991). Evolution of macro-information systems for sustainable development. Ecological Economics, 3(1), 59-76. https://doi.org/10.1016/0921-8009(91)90048-J 
Geogescu-Roegen, N. (1971). The Entropy Law and the Economic Process. Cambridge, Massachusetts: Harvard University Press.

Giampietro, M., \& Saltelli, A. (2014). Footprints to nowhere. Ecological Indicators, 46, 610-621. https://doi.org/10.1016/j.ecolind.2014.01.030

Gibson, R. B., Hassan, S., Holtz, S., Tansey, J., \& Whitelaw, G. (2005). Sustainability Assessment: Criteria, Processes and Applications. London: Earthscan,

Guzmán, G. I., Molina, M. G., \& Alonso, A. M. (2011). The land cost of agrarian sustainability. An assessment. Land Use Policy, 28, 825-835. https://doi.org/10.1016/j.landusepol.2011.01.010

Hodas, D. R. (2013). Law, the laws of nature and ecosystem energy services: a case of wilful blindness. PER: Potchefstroomse Elektroniese Regsblad, 16(2), 67-121.

Huang, S. L., Wong, J. H., \& Chen, T. C. (1998). A framework of indicator system for measuring Taipei's urban sustainability. Landscape and Urban Planning, 42, 15-27. https://doi.org/10.1016/S0169-2046(98)00054-1

Huber, M. W. (2009). Energizing historical materialism: Fossil fuels, space and the capitalist mode of in physical reality. Energy Policy, 36, 4600-4604.

Ingebrigtsen, S., \& Jakobsen, O. (2012). Utopias and realism in ecological economics-Knowledge, $\begin{array}{llll}\text { understanding and improvisation. Ecological } & \text { Economics, } & \text { 84, } & \text { 84-90. }\end{array}$ https://doi.org/10.1016/j.ecolecon.2012.09.015

Jenkins, T. N. (1996). Democratising the global economy by ecologicalising economics: The example of global warming. Ecological Economics, 16(3), 227-238. https://doi.org/10.1016/0921-8009(95)00090-9

Kates, R. W., Parris, T. M., \& Leiserowitz, A. A. (2005). What is sustainable development? Environmental Science and Policy, 47(3), 8-21.

Klaassen, G. A. J., \& Opschoor, J. B. (1991). Economics of sustainability or the sustainability of economics: different paradigms. Ecological Economics, 4, 93-115. https://doi.org/10.1016/0921-8009(91)90024-9

Klitgaard, K. A., \& Krall, L. (2012). Ecological economics, degrowth, and institutional change. Ecological Economics, 84, 247-253. https://doi.org/10.1016/j.ecolecon.2011.11.008

Korhonen, J., \& Niutanen, V. (2003). Material and energy flows of a local forest industry system in Finland. Sustainable Development, 11, 121-132.

Lawn, P. A. (2001). Scale, prices, and biophysical assessments. Ecological Economics, 38(3), 369-382. https://doi.org/10.1016/S0921-8009(01)00172-0

Li, F., Liu, X., Hu, D., Wang, R., Yang, W., Li, D., \& Zhao, D. (2009). Measurement indicators and an evaluation approach for assessing urban sustainable development: A case study for China's Jining City. Landscape and Urban Planning, 90, 134-142. https://doi.org/10.1016/j.landurbplan.2008.10.022

Lintott, J. (1998). Beyond the economics of more: the place of consumption in ecological economics. Ecological Economics, 25(3), 239-248. https://doi.org/10.1016/S0921-8009(97)00042-6

Lucena, A. D., Cavalcante, J. N., \& Cândido, G. A. (2011). Sustentabilidade do município de João Pessoa: uma aplicação do barômetro da sustentabilidade. Revista Brasileira de Gestão e Desenvolvimento Regional, 7 , 19-49.

Macrae, R. J., Henning, J., \& Hill, S. B. (1993). Strategies to overcome barriers to the development of sustainable agriculture in Canada: The role of agribusiness. Journal of Agricultural and Environmental Ethics, 6(1), 21-51.

Martinez-Alier, J. (1997). Some issues in agrarian and ecological economics, in memory of Georgescu-Roegen. Ecological Economics, 22, 225-238. https://doi.org/10.1016/S0921-8009(97)00076-1

Martinez-Alier, J. (2001). Mining conflicts, environmental justice, and valuation. Journal of Hazardous Materials, 86(1-3), 153-170. https://doi.org/10.1016/S0304-3894(01)00252-7

Mcmahon, M. (1997). From the ground up: ecofeminism and ecological economics. Ecological Economics, 20 , 163-173. https://doi.org/10.1016/S0921-8009(96)00026-2

Meadows, D. (1998). Indicators and informations systems for sustainable development. Hart-Land Four Corners: The Sustainability Institute.

Meppem, T., \& Gill, R. (1998). Planning for sustainability as a learning concept. Ecological Economics, 26(2), 


\section{1-137. https://doi.org/10.1016/S0921-8009(97)00117-1}

Moreno-Pires, S., \& Fidélis, T. (2012). A proposal to explore the role of sustainability indicators in local governance contexts: The case of Palmela, Portugal. Ecological Indicators, 23, 608-615. https://doi.org/10.1016/j.ecolind.2012.05.003

Moussiopoulos, N., Achilllas, C., Vlachokostas, C., Spyridi, D., \& Nikolaou, K. (2010). Environmental, social and economic information management for the evaluation of sustainability in urban areas: A system of indicators for Thessaloniki, Greece. Cities, 27, 377-384. https://doi.org/10.1016/j.cities.2010.06.001

Nadeau, R. L. (2015). The unfinished journey of ecological economics. Ecological Economics, 109, 101-108. https://doi.org/10.1016/j.ecolecon.2014.11.002

Nader, M. R., Salloum, B. A., \& Karam, N. (2008). Environment and sustainable development indicators in Lebanon: A practical municipal level approach. Ecological Economics, 8, 771-777. https://doi.org/10.1016/j.ecolind.2007.09.001

Ness, B., Urbel-Piirsalu, E., Anderberg, S., \& Olsson, L. (2007). Categorising tools for sustainability assessment, Ecological Economics, 60, 498-508. https://doi.org/10.1016/j.ecolecon.2006.07.023

Nihoul, J. C. J. (1998). Modelling Sustainable Development as a Problem in Earth Science. Mathematical and Computer Modelling, 28(10), 1-6. https://doi.org/10.1016/S0895-7177(98)00150-2

Nobre, A. M., Musango, J. K., Wit, M. P., \& Ferreira, J. G. (2009). A dynamic ecological-economic modeling approach for aquaculture management. Ecological Economics, 68(12), 3007-3017. https://doi.org/10.1016/j.ecolecon.2009.06.019

Noël, J. F., O'Connor, M., \& Sang, S. T. K. (2000). The Bouchereau woodland and the transmission of socio-ecological economic value. Ecological Economics, 34(2), 247-266. https://doi.org/10.1016/S0921-8009(00)00161-0

O'Connor, M. (1991). Entropy, structure, and organisational change. Ecological Economics, 3(2), 95-122. https://doi.org/10.1016/0921-8009(91)90012-4

Ockwell, D. G. (2008). Energy and economic growth: Grounding our understanding in physical reality. Energy Policy, 36, 4600-4604. https://doi.org/10.1016/j.enpol.2008.09.005

Odum, H. (1973). Energy, ecology and economics. Swedish Academy of Science. AMBIO, 2(6), 220-227.

O'hara, P. A. (2009). Political economy of climate change, ecological destruction and uneven development. Ecological Economics, 69(2), 223-234. https://doi.org/10.1016/j.ecolecon.2009.09.015

Özkaynak, B., Adaman, F., \& Devine, P. (2012). The identity of ecological economics: Retrospects and prospects. Cambridge Journal of Economics, 36(5), 1123-1142. https://doi.org/10.1093/cje/bes021

Pearce, D. (1987). Foundations of an Ecological Economics. Ecological Modelling, 38, 9-18. https://doi.org/10.1016/0304-3800(87)90042-1

Pelletier, N. (2010). Environmental sustainability as the first principle of distributive justice: Towards an ecological communitarian normative foundation for ecological economics. Ecological Economics, 69(10) 1887-1894. https://doi.org/10.1016/j.ecolecon.2010.04.001

Pelletier, N. (2010). Of laws and limits: An ecological economic perspective on redressing the failure of contemporary global environmental governance. Global Environmental Change, 20, 220-228. https://doi.org/10.1016/j.gloenvcha.2009.12.006

Pelletier, N., Maas, R., Goralczyk, M., \& Wolf, A. (2014). Conceptual basis for development of the European $\begin{array}{llll}\text { Sustainability } \quad \text { Footprint. } & \text { Environmental } & \text { Development, } & \text { 9, }\end{array}$ https://doi.org/10.1016/j.envdev.2013.12.003

Portney, K. (2002). Taking Sustainable Cities Seriously: A comparative analysis of twenty-four US cities. Local Environment Production. Geoforum, 40, 105-115. http://dx.doi.org/10.1080/1354983022000027491

Rametsteiner, E., Pülzl, H., Alkan-Olsson, J., \& Frederiksen, P. (2011). Sustainability indicator development-Science or political negotiation? Ecological Indicators, 11, 61-70. https://doi.org/10.1016/j.ecolind.2009.06.009

Rammelt, C. F. \& Boes, J. (2013). Galtung meets Daly: A framework for addressing inequity in ecological economics. Ecological Economics, 93, 269-277. https://doi.org/10.1016/j.ecolecon.2013.06.013 
Røpke, I. (2004). The early history of modern ecological economics. Ecological Economics, 50, 293-314. https://doi.org/10.1016/j.ecolecon.2004.02.012

Røpke, I. (2009). Theories of practice-New inspiration for ecological economic studies on consumption. Ecological Economics, 68, 2490-2497. https://doi.org/10.1016/j.ecolecon.2009.05.015

Røpke, I. (2016). Complementary system perspectives in ecological macroeconomics-The example of transition investments during the crisis. Ecological Economics, 121, 237-245. https://doi.org/10.1016/j.ecolecon.2015.03.018

Roberts, T. D. (2011). Applying the STIRPAT model in a post-Fordist landscape: Can a traditional econometric model work at the local level? Applied Geography, 31(2), 731-739. https://doi.org/10.1016/j.apgeog.2010.06.010

Rosales, N. (2011). Towards the modeling of sustainability into urban planning: Using indicators to build sustainable cities. Procedia Engineering, 21, 641-647. https://doi.org/10.1016/j.proeng.2011.11.2060

Schandl, H., \& Schulz, N. (2002). Changes in the United Kingdom's natural relations in terms of society's metabolism and land-use from 1850 to the present day. Ecological Economics, 41(2), 203-221. https://doi.org/10.1016/S0921-8009(02)00031-9

Schneider, F., Kallis, G., \& Martinez-Alier, J. (2010). Crisis or opportunity? Economic degrowth for social equity and ecological sustainability. Introduction to this special issue. Journal of Cleaner Production, 18(6), 511-518. https://doi.org/10.1016/j.jclepro.2010.01.014

Scipioni, A., Mazzi, A., Mason, M., \& Manzardo, A. (2009). The Dashboard of Sustainability to measure the local urban sustainable development: The case study of Padua Municipality. Ecological Indicators, 9, 364-380. https://doi.org/10.1016/j.ecolind.2008.05.002

Shen, L. Y., Ochoa, J. J., Shah, M. N., \& Zhang, X. (2011). The application of urban sustainability indicators-A comparison between various practices. Habitat International, 35, 17-29. https://doi.org/10.1016/j.habitatint.2010.03.006

Shi, T. (2002). Ecological economics in China: origins, dilemmas and prospects. Ecological Economics, 41(1), 5-20. https://doi.org/10.1016/S0921-8009(02)00025-3

Sousa, T., \& Domingos, T. (2006). Is neoclassical microeconomics formally valid? An approach based on an analogy with equilibrium thermodynamics. Ecological Economics, 58, 160-169. https://doi.org/10.1016/j.ecolecon.2005.07.004

Stahel, A. W. (2005). Value from a complex dynamic system's perspective. Ecological Economics, 54, 370-381. https://doi.org/10.1016/j.ecolecon.2005.03.024

Stem, D. I. (1997). Limits to substitution and irreversibility in production and consumption: A neoclassical interpretation of ecological economics. Ecological Economics, 21, 197-215. https://doi.org/10.1016/S0921-8009(96)00103-6

Summers, J. K., Smith, L. M., Case, J. L., \& Linthurst, R. A. (2012). A review of the elements of human well-being with an emphasis on the contribution of ecosystem services. Ambio, 41, 327-340.

Tanguay, G. A., Rajaonson, J., Lefebvre, J. F., \& Lanoie, P. (2010) Measuring the sustainability of cities: An analysis of the use of local indicators. Ecological Indicators, 10, 407-418. https://doi.org/10.1016/j.ecolind.2009.07.013

UlhфI, J. P. (1995). Corporate environmental and resource management: In search of a new managerial paradigm. European Journal of Operation Research, 80(1), 2-15. https://doi.org/10.1016/0377-2217(94)00089-U

United Nations Conference on Sustainable Development. (1992). Agenda 21, Programme of Action for Sustainable Development, adopted at the United Nations Conference on Environment and Development, Rio de Janeiro, Brazil.

Victor, P. A. (2015). The Kenneth E. Boulding Memorial Award 2014: Ecological economics: A personal journey. Ecological Economics, 109, 93-100. https://doi.org/10.1016/j.ecolecon.2014.11.009

Warlenius, R., Pierce, G., \& Ramasar, V. (2015). Reversing the arrow of arrears: The concept of "ecological debt" and its value for environmental justice. Global Environmental Change, 30, 21-30.

Weaver, R. C. (2013). Re-framing the urban blight problem with trans-disciplinary insights from ecological economics. Ecological Economics, 90, 168-176. https://doi.org/10.1016/j.ecolecon.2013.03.009 


\section{Copyrights}

Copyright for this article is retained by the author(s), with first publication rights granted to the journal.

This is an open-access article distributed under the terms and conditions of the Creative Commons Attribution license (http://creativecommons.org/licenses/by/4.0/). 